\title{
BALL THROMBUS OF THE HEART
}

\author{
BY \\ M. E. EVANS \\ From Joyce Green Hospital, Dartford, Kent \\ Received December 10, 1947
}

Although ball thrombus of the heart has always been of considerable interest, Abramson in 1924 was able to collect only 19 reported cases and added 1 of his own. The condition was first reported in 1814 by William Wood of Edinburgh in a delicate girl of 15: for three years she had been subject to progressive dyspnca on exertion, and began to suffer from fainting spells three or four times a day, and eventually died in a state of exhaustion. Postmortem, there was a round, firm mass lying completely free in the left auricle; the mitral valve was greatly thickened and the orifice too small to admit the tip of the little finger. In the succeeding 110 years a further 19 cases were reported, of which 6 occurred in the British Isles. In the 15 cases in which the sex was given, 11 were females and 4 males, an incidence corresponding to the sex distribution of mitral stenosis. Most were in the fifth decade of life. Eight of these 20 cases showed either transient or permanent disturbance of the peripheral vascular system. The site of the thrombus was in the left auricle, except in the case described by French (1912) where it was in the right ventricle. Since Abramson's review, a further 12 cases have been recorded, 11 associated with mitral stenosis and 1 with a normal mitral valve. The thrombi have been found in the left auricle, except in the case reported by Wright, Flynn, and Druet (1944) of a thrombus in the right auricle. Ten of these 12 patients had interference with the circulation in the lower limbs. The details of these cases are shown in the table.

During the same period 4 cases were described resembling the condition reported here, but not due to ball thrombi. Kaplan and Hollingsworth (1935) recorded a case of pedunculated thrombus of the left auricle simulating mitral stenosis; post-mortem the thrombus occluded a normal mitral valve; there was no interference with the peripheral circulation. Schiller (1935) reported two cases of subacute bacterial endocarditis in which the exuberant vegetations on the mitral valve attained a size sufficient to produce transient circulatory disturbances in the limbs. Perry and Davie (1939) described a case of symmetrical peripheral gangrene in a man, aged 64, with cardiac failure and a blood pressure of $175 / 85$. Post-mortem, no valvular disease of the heart could be found; there was a moderate degree of atheroma of the aorta, but no evidence of thrombosis, embolus, or atheroma of the iliac, femoral, or popliteal arteries. They quote this case in support of Fishberg's (1938) theory that in severe congestive cardiac failure a selective vaso-constriction occurs (? reflexly) because of extreme diminution in the cardiac output, a small amount of blood being distributed to the limbs and a large amount to the brain and other important centres. In support of his theory, Fishberg quotes a case in which, on inserting a cannula into the antecubital vein, the venous pressure was under $1 \mathrm{~cm}$., whereas at the same time the jugular pressure was over $20 \mathrm{~cm}$. As the patient improved the pressures became equalized. In his view, peripheral gangrene in general circulatory failure is an unfortunate side effect of a valuable compensating mechanism.

The term ball thrombus of the heart is applied to a form of ante-mortem thrombus, and the criteria for calling a given ante-mortem clot a ball thrombus have been variously stated. According to Hewitt (1916) " the term ball or oval thrombus of the heart should be restricted to those thrombi found on post-mortem examination, loose in the heart cavities, which are of a round or oval shape and whose surface is everywhere smooth and shows no sign of a former attachment." Abramson and most other observers prefer to substitute for the last part the criteria of Welch (1899), viz., (a) entire absence of attachment with consequent free mobility; (b) imprisonment in consequence of an excess of the diameter of the thrombus over that of the first narrowing in the circulatory passage ahead of it; (c) such consistency and shape that the thrombus must not of necessity lodge as an embolus in the 
Table of some Details of Reported Cases of Ball Thrombus

\begin{tabular}{|c|c|c|c|c|c|}
\hline $\begin{array}{l}\text { Sex, age, and } \\
\text { author }\end{array}$ & $\begin{array}{l}\text { Clinical course } \\
\text { and symptoms }\end{array}$ & $\begin{array}{c}\text { Thrombus: } \\
\text { localization, } \\
\text { size, and weight }\end{array}$ & $\begin{array}{l}\text { Peripheral } \\
\text { vascular } \\
\text { disturbance }\end{array}$ & $\begin{array}{l}\text { Other dis- } \\
\text { turbances } \\
\text { of circulation } \\
\text { and B.P. }\end{array}$ & $\begin{array}{l}\text { Final anatomical } \\
\text { diagnosis }\end{array}$ \\
\hline F, 53, Potter & $\begin{array}{l}2 \frac{1}{2} \text { years dyspnœa. } \\
\text { Thyrotoxicosis. } \\
\text { A.F. }\end{array}$ & $\begin{array}{l}\text { L.A. Spherical } \\
\mathbf{4 8} \mathrm{g} \text {. }\end{array}$ & $\underset{\text { legs }}{\text { Gangrene of both }}$ & $\begin{array}{l}\text { Infarcts of spleen } \\
\text { and kidneys } \\
160 / 100\end{array}$ & $\begin{array}{l}\text { M.S.(buttonhole) } \\
\text { Ball thrombus }\end{array}$ \\
\hline $\begin{array}{l}\text { F, 55, Covey, Crook, } \\
\text { and Rogers }\end{array}$ & $\begin{array}{l}4 \text { years dyspnœa; } \\
6 \text { months swelling } \\
\text { of ankles. A.F. }\end{array}$ & $\begin{array}{l}\text { L.A. Spherical } \\
16 \mathrm{~g} \text {. }\end{array}$ & Gangrene R. leg & $\begin{array}{l}\text { Infarcts of kid- } \\
\text { neys } 165 / 90\end{array}$ & $\begin{array}{l}\text { M.S. (button- } \\
\text { hole) Ball } \\
\text { thrombus }\end{array}$ \\
\hline $\begin{array}{l}\mathrm{F}, 44, \text { Schwartz, and } \\
\text { Biloon, Case } 1\end{array}$ & $\begin{array}{l}\text { Palpitation 10 } \\
\text { years. A.F. }\end{array}$ & L.A. Pyramidal & Gangrene R. leg & ? 190/90 & $\begin{array}{l}\text { M.S. Ball } \\
\text { thrombus }\end{array}$ \\
\hline $\begin{array}{l}\text { F, 42, Schwartz and } \\
\text { Biloon, Case } 2\end{array}$ & $\begin{array}{l}\text { Cardiac failure } 2 \\
\text { years. A.F. one } \\
\text { month }\end{array}$ & L.A. Spherical & $\begin{array}{l}\text { Attacks of pallor } \\
\text { in R. leg-gan- } \\
\text { grene }\end{array}$ & Nil $190 / 110$ & $\begin{array}{l}\text { M.S. Ball } \\
\text { thrombus }\end{array}$ \\
\hline $\begin{array}{l}\text { M, 62, Schwartz and } \\
\text { Biloon, Case } 3\end{array}$ & $\begin{array}{l}\text { Cardiac failure } 2 \\
\text { months. A.F. }\end{array}$ & L.A. Cylindrical & $\begin{array}{l}\text { Gangrene of both } \\
\text { legs. Attacks of } \\
\text { cyanosis lead- } \\
\text { ing to gangrene } \\
\text { of } R \text {. hand }\end{array}$ & $? 140 / 80$ & $\begin{array}{l}\text { Ball thrombus. } \\
\text { No M.S. }\end{array}$ \\
\hline F, 52, Elson & $\begin{array}{l}\text { Præcordial pain } 8 \\
\text { years. A.F. } 3 \\
\text { years }\end{array}$ & $\begin{array}{l}\text { L.A. Oval } \\
4 \times 0.5 \mathrm{~cm} \text {. }\end{array}$ & $\begin{array}{l}\text { Attacks of pallor } \\
\text { and coldness } \\
\text { of both lower } \\
\text { limbs. Weak- } \\
\text { ness of R. radial } \\
\text { pulse }\end{array}$ & $\begin{array}{l}\text { Old infarcts in } \\
\text { spleen and kid- } \\
\text { neys } 230 / 80\end{array}$ & $\begin{array}{l}\text { Buttonhole M.S. } \\
\text { Ball thrombus }\end{array}$ \\
\hline $\begin{array}{l}\text { F, 43, Aronstein } \\
\text { and Neuman }\end{array}$ & $\begin{array}{l}\text { Dizzy spells } 5 \\
\text { years. Dyspnoa } \\
\text { and cyanosis of } \\
\text { face } 2 \text { days }\end{array}$ & $\begin{array}{l}\text { L.A. Spherical } \\
3.5 \mathrm{~cm} \text {. in dia- } \\
\text { meter }\end{array}$ & Nil & $\begin{array}{l}\text { Infarcts in spleen. } \\
\text { B.P.? }\end{array}$ & $\begin{array}{l}\text { Ball thrombuis. } \\
\text { M.S. }\end{array}$ \\
\hline F, 48, Garvin, Case & $\begin{array}{l}\text { Faints for several } \\
\text { years. After D. } \\
\text { and C. developed } \\
\text { A.F. and gan- } \\
\text { grene of R. foot } \\
\text { and calf. No } \\
\text { pulse in L. foot }\end{array}$ & $\begin{array}{l}\text { L.A. Spherical } \\
3 \mathrm{~cm} \text {. in dia- } \\
\text { meter }\end{array}$ & Gangrene of both & $\begin{array}{l}\text { Infarcts of spleen } \\
\text { and kidneys. } \\
\text { B.P.? }\end{array}$ & $\begin{array}{l}\text { M.S. Tricuspid } \\
\text { stenosis. Ball } \\
\text { thrombus. } \\
\text { Embolism }\end{array}$ \\
\hline F, 86, Garvin, Case & $\begin{array}{l}\text { Faints } 2 \text { years. } \\
\text { A.F. Blackening } \\
\text { of } R \text {. foot for } 2 \\
\text { days }\end{array}$ & $\begin{array}{l}\text { L.A. Spherical } \\
2 \cdot 2 \mathrm{~cm} \text {. dia- } \\
\text { meter }\end{array}$ & $\begin{array}{l}\text { Gangrene of R. } \\
\text { foot }\end{array}$ & $\begin{array}{l}\text { Thrombosis of R. } \\
\text { femoral and } \\
\text { popliteal } \\
\text { arteries. B.P.? }\end{array}$ & $\begin{array}{l}\text { Coronary } \\
\text { sclerosis. M.S. } \\
\text { Ball thrombus }\end{array}$ \\
\hline$\underset{3}{\mathrm{M}}, 46$, Garvin, Case & $\begin{array}{l}\text { Hemiplegia and } \\
\text { cardiac failure. } \\
\text { Sudden death. } \\
\text { A.F. }\end{array}$ & $\begin{array}{l}\text { L.A. Oval } \\
2 \mathrm{~cm} \text {. in dia- } \\
\text { meter }\end{array}$ & Nil & $\begin{array}{l}\text { Infarcts in spleen, } \\
\text { kidneys, lungs, } \\
\text { and brain. } \\
\text { B.P.? }\end{array}$ & $\begin{array}{c}\text { M.S. Ball } \\
\text { thrombus }\end{array}$ \\
\hline F, 33, Spain & $\begin{array}{l}\text { Cardiac asthma. } \\
\text { Transcient vascu- } \\
\text { lar phenomena in } \\
\text { limbs leading to } \\
\text { gangrene. Regu- } \\
\text { lar rhythm }\end{array}$ & $\begin{array}{l}\text { L.A. Spherical } \\
3 \mathrm{~cm} \text {. in dia- } \\
\text { meter }\end{array}$ & $\begin{array}{l}\text { Gangrene of } \\
\text { limbs }\end{array}$ & $\begin{array}{l}\text { Infarcts of } R . \\
\text { lung and both } \\
\text { kidneys }\end{array}$ & $\begin{array}{c}\text { M.S. Ball } \\
\text { thrombus }\end{array}$ \\
\hline $\begin{array}{l}\text { M, 47, Wright, } \\
\text { Flynn, and Druet }\end{array}$ & $\begin{array}{l}\text { Dyspnœa } 24 \text { years. } \\
\text { Failure for } 6 / 12 \text {. } \\
\text { Hemiplegia. }\end{array}$ & $\begin{array}{l}\text { R. auricle. } \\
\text { Spherical } 6 \cdot 8 \\
\mathrm{~cm} \text {. in diameter }\end{array}$ & $\begin{array}{l}\text { Pulsation of neck } \\
\text { veins, occasion- } \\
\text { ally of saphen- } \\
\text { ous veins }\end{array}$ & $\begin{array}{l}\text { Infarcts of left } \\
\text { kidney, spleen, } \\
\text { and mesenteric } \\
\text { artery. Pontine } \\
\text { hæmorrhage } \\
100 / 90\end{array}$ & $\begin{array}{l}\text { M.S. Tricuspid } \\
\text { regurgitation. } \\
\text { Ball thrombus } \\
\text { in R. auricle }\end{array}$ \\
\hline
\end{tabular}
A.F. $=$ Auricular fibrillation.
AbBreViations:-
L.A. $=$ Left auricle. $\quad$ M.S. $=$ Mitral stenosis.

passage. The cases reported by Abramson and those described in the table all appear to fulfil the criteria laid down by Welch.

In view of its rarity and the comparative paucity of cases recorded in England, the case described below was considered worth recording. Although presenting most of the characteristics of the syndrome, it also showed certain unusual features. 


\section{CASE History}

A woman, aged 50 years, was admitted to hospital on December 29, 1946, her chief complaints being blueness and coldness of the legs and an inability to move them. She had chorea at the age of 13 , and was in bed for about a year, but never had acute rheumatic fever. Subsequently, she led an extremely active life, played outdoor games and, during the late war, worked hard in a canteen. She was married, but had no children. A fortnight before admission, after a long day out, she noticed for the first time that she was a little short of breath and had slight swelling of her ankles. She stayed in bed and was digitalized by her doctor. Her dyspnœa and œdema subsided and on Christmas Day she was allowed up for lunch. In the afternoon she walked upstairs and was suddenly seized with a violent pain around her umbilicus. She was sick once and later passed several tarry motions. The abdominal pain gradually disappeared. Shortly after vomiting she had severe pain in both legs, the right worse than the left; with the pain the legs became numb and cold. At first they were white, but later they turned blue. The blueness and numbness persisted but the pain gradually disappeared.

On admission her lips and cheeks were slightly cyanosed and a little dyspnœa was present. The cervical veins were distended to a height of two inches above the clavicle with the patient upright. Clinically, there was no enlargement of the heart, which was fibrillating at a rate of 60 ; an apical systolic murmur was heard, but no diastolic murmur. The blood pressure in the right arm was 170/110; it could not be recorded in the left. Examination of the lungs rèvealed no abnormality. The central part of the abdomen was tender on palpation, but there was no rigidity. Her hands were blue and cold, although the pulses were palpable and of fairly good volume. The right leg was blue and cold to just above the knee, where a sharp line of demarcation was present, but above this level it was pink and warm. The toes showed dry gangrene. The femoral pulse was palpable; popliteal pulsation was absent and pressure over the origin of the profunda femoris artery was painful. No voluntary movement was possible and the affected part of the leg was anæsthetic. The left leg was blue and cold to just above the ankle and gangrene of the toes was commencing. Again the femoral, but not the popliteal, pulse was palpable. Slight voluntary movement of the foot and toes was possible and there was no anæsthesia. Half-anhour after admission the circulation in the hands had returned to normal - they were quite pink and warm-but there was no change in the legs. The following day she again developed a transient cyanosis and numbness of the hands. The upper margin of the cyanosis of the right leg had decreased to just below the knee. The patient was seen at this stage by my colleague, Dr. Goldstein, who suggested that she might be suffering from a ball thrombus of the left auricle. The urinary output was very difficult to estimate because of incontinence; a catheter specimen showed a heavy trace of protein, occasional pus cells and red cells, occasional hyaline casts, and amorphous phosphates. Unfortunately, an electrocardiograph could not be performed as the apparatus was being repaired. On December 31 she was becoming very drowsy and passing practically no urine. The blood urea was $300 \mathrm{mg}$. per $100 \mathrm{ml}$. The following day her condition continued to deteriorate and she died in the evening.

\section{Post-Mortem Examination}

This was performed on January 2, by Dr. A. M. Bodoano. There was gangrene of the right foot which spread up the leg to just below the knee as a reddish-purple discoloration. This discoloration was also present in the left foot and extended about three inches above the ankle.

Thorax. There was no free fluid in the pleural cavities or pericardium. The heart was greatly enlarged, and weighed about $500 \mathrm{~g}$. As the left auricle was opened, a firm ovoid mass fell out ; it was covered by velvety fibrin which, when washed off, left behind a perfectly smooth ovoid clot. There was no sign of any point of attachment to the auricular wall and it appeared to be quite free in the auricle (Fig. 1 and 2). It weighed $23 \mathrm{~g}$. after fixation in formol saline. Section of the clot showed it to be of uniform structure and unlaminated. The right auricle was dilated and its wall thinned. The right ventricle was hypertrophied, its wall being 1.0 $\mathrm{cm}$. in thickness. The wall of the left auricle was stretched and thinned and was everywhere smooth, showing no sign of any previous attachment of the thrombus. The wall of the left ventricle showed a. concentric hypertrophy, the average thickness of muscle being $1.8 \mathrm{~cm}$. The mitral orifice was - stenosed, just admitting the tip of the index finger and had the " button-hole" type of deformity; the orifice was $2.5 \mathrm{~cm}$. in length and a mere slit in breadth. The cusps were greatly thickened and partially calcified; the chordæ tendiniæ were adherent. The tricuspid, pulmonary, and aortic valves, and the coronary arteries were normal. The wall of the thoracic aorta was perfectly smooth. The lungs were œdematous but showed no sign of infarction. There were no thrombi in the pulmonary vessels.

Abdomen. The peritoneal cavity contained a 


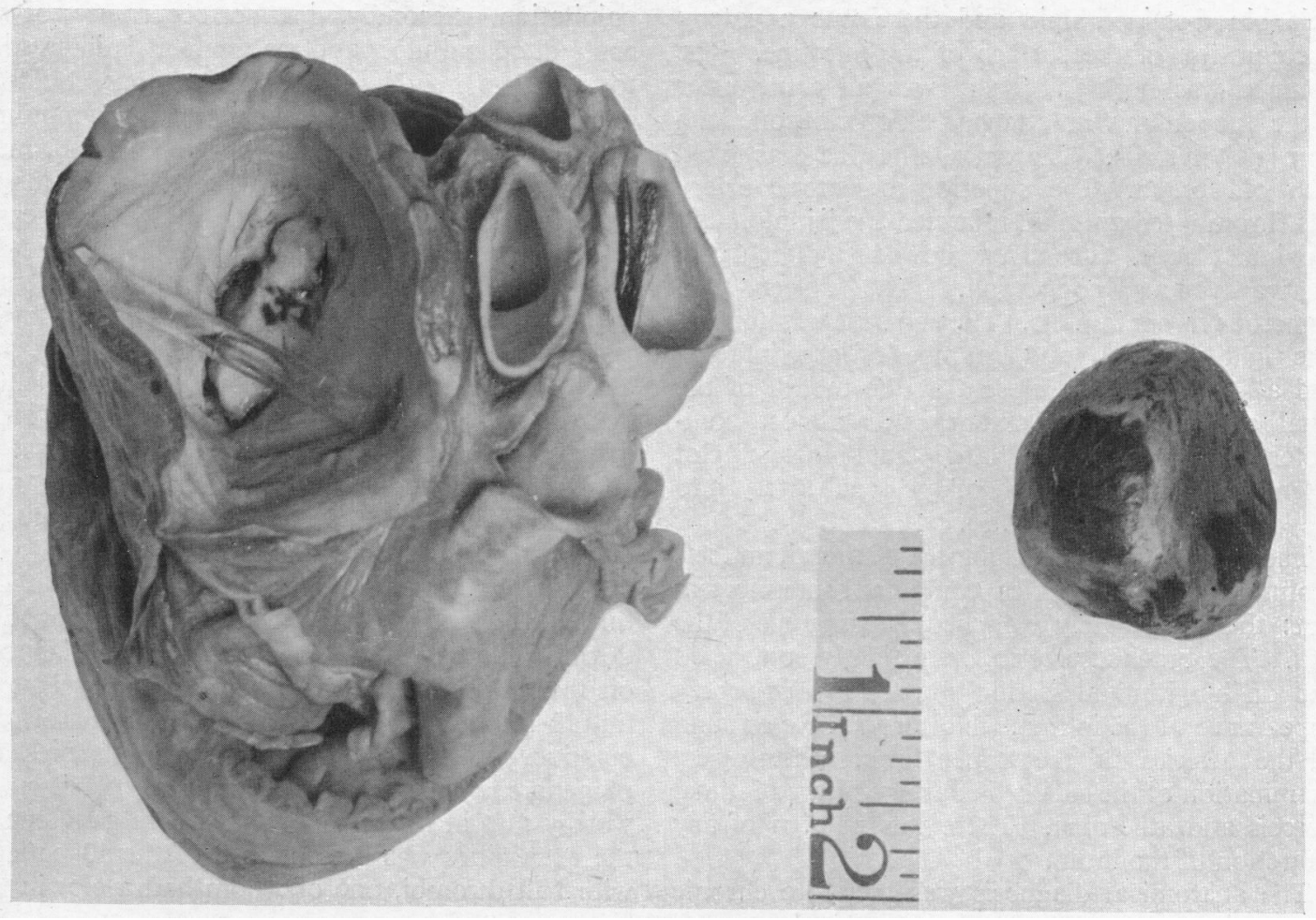

FIG. 1.-Photograph of the heart showing mitral valve and the ball thrombus.

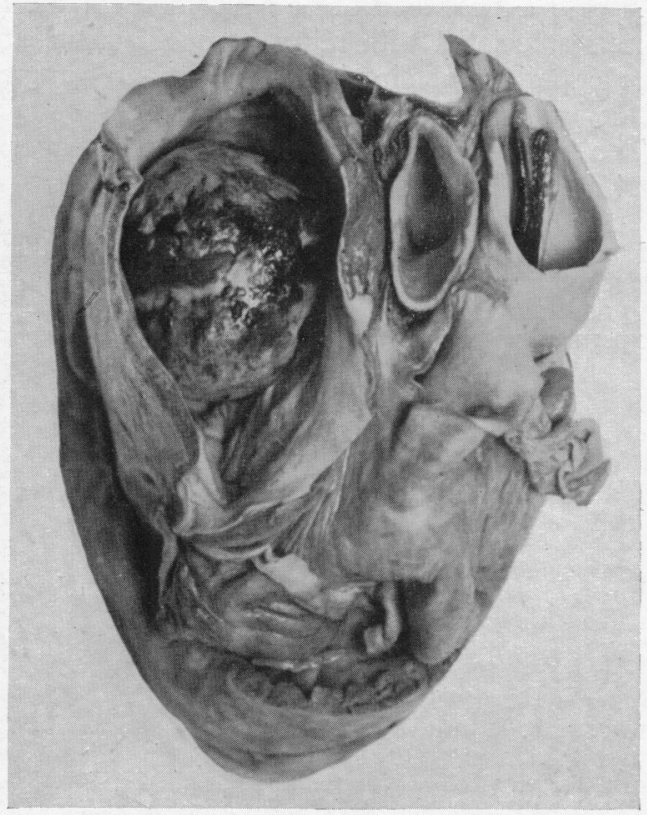

FIG. 2.-Ball thrombus in situ.

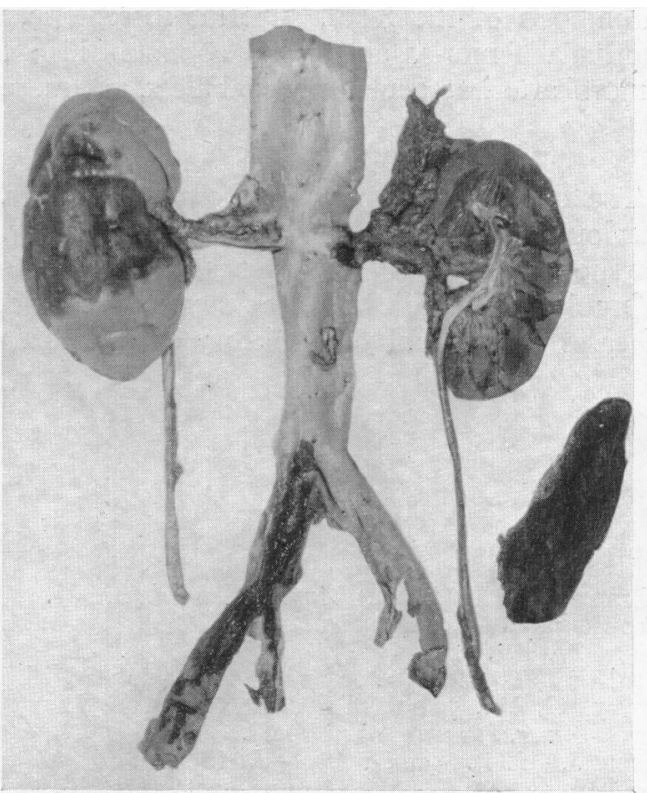

FIG. 3.-Dissection of abdominal aorta, renal arteries and kidneys and spleen, to show thrombi in situ and infarction of viscera. 
little blood-stained fluid and there was a patchy discoloration of the surface of the intestine. The stomach was normal. There was an acute ulcer in the duodenum with attached blood clot, one inch from the pylorus. The small intestine was filled with old blood. The superior mesenteric artery was thrombosed and had infarcted the jejunum and proximal ileum. The liver showed slight chronic passive venous congestion. The spleen had numerous recent infarcts. The pancreas was normal. The right kidney showed a number of large infarcts, and a small clot was present at the mouth of the renal artery. The left kidney was almost completely infarcted by a large ante-mortem clot extending from the mouth of the renal artery into the kidney substance (Fig. 3).

The descending aorta, right iliac, femoral, and left profunda femoris arteries contained ante-mortem clot: these adequately explained the gangrene of the legs. The brachial arteries were tightly contracted and on longitudinal section showed a sand-papery appearance of the intima. No thrombi were found in the arteries of the upper limb. Histological examination of the subclavian artery showed intimal fibrosis and atheroma. There was no sign of any infarction of the brain.

The anatomical diagnosis was therefore chronic rheumatic endocarditis leading to mitral stenosis and auricular fibrillation; free ball thrombus of the left auricle; embolic phenomena in the spleen, and thrombosis of the renal, superior mesenteric, left profunda femoris, and right common iliac and femoral arteries; acute duodenal ulcer, and melæna.

\section{Discussion}

The case described differs from most of those previously recorded in several aspects. Firstly, in the short history, only three weeks, of any symptoms referable to the cardiovascular system. The majority of cases had several years history of dyspnœa and palpitation. Secondly, in the occurrence of an acute duodenal ulcer and melæna. It is interesting to speculate how long a ball thrombus could be present in the auricle without producing symptoms. This clot, although not laminated on section, must have been present for a period considerably longer than three weeks. In only one of the later cases of Abramson's series is the occurrence of auricular fibrillation specifically mentioned. In cases subsequently reported, however, auricular fibrillation was present in all but one. Unfortunately, the date of onset of auricular fibrillation in this patient is not known, but it is likely to have been at the onset of her dyspnœa and slight œdema. The onset of auricular fibrillation may therefore act as a precipitating factor for the development of symptoms from a ball thrombus.

The criteria for the diagnosis during life of a ball thrombus of the heart are still the same as those laid down by Battistini (1908), who based the diagnosis on the following sequence of symptoms: signs of mitral stenosis, disturbance of the general circulation, entire debility of the pulse, and the presence of gangrene of the lower extremities. It is noteworthy that in the series analysed here gangrene of the extremities was present in 8 of the 13 patients with ball thrombi, one of whom had a clot in the right auricle.

\section{SUMMARY}

A case is described of ball thrombus of the left auricle associated with mitral stenosis, disturbance of the peripheral circulation leading to gangrene of the legs, and acute duodenal ulcer.

The cases occurring since Abramson's paper in 1924 are reviewed.

I am grateful to Dr. M. Mitman, Medical Superintendent of the River Hospitals, Dartford, for much help and criticism in the preparation of this article and for permission to publish the case.

\section{REFERENCES}

Abramson, J. L. (1924). Ann. clin. Med., 3, 327.

Aronstein, C. G., and Newman, L. (1939). Arch. Path., 27, 907.

Battistini (1908-9). G. Accad. Med. Torina, 14-15, 313.

Covey, G. W., Crook, R., and Rogers, F. L. (1928). Amer. J. med. Sci., 175, 60.

Elson, J. (1934). Amer. Heart J., 15, 120.

Fishberg, A. M. (1938). J. clin. Invest., 17, 510.

French, H. (1912). Guy's Hosp. Rep., 66, 353.

Garvin, C. F. (1941). Amer. Heart J., 21, 371.

Hewitt, J. H. (1916). Johns Hopk. Hosp. Rep., 17, 1-80.
Kaplan, D., and Hollingsworth, E. W. (1935). J. Amer. med. Ass., 105, 1264.

Perry, C. B., and Davie, T. B. (1939). Brit. med. J., 1, 15.

Potter, E. B. (1926). Ann. clin. Med., 4, 736.

Schiller, I. A. (1935). J. Mt. Sinai Hosp., 2, 153.

Schwartz, S. P., and Biloon, S. (1931). Amer. Heart J., 7,84 .

Spain, D. M. (1943). Ann. intern. Med., 19, 144.

Welch, W. H. (1899). Albutt's System of Medicine, 7,185.

Wood, W. (1814). Edinb. Med. and Surg. J., 10, 50.

Wright, I. S., Flynn, J. E., and Druet, K. L. (1944). Amer. Heart J., 27, 858. 